\title{
Lettuce Cultivars Suitable for Use in Southern Florida ${ }^{1}$
}

\author{
Huangjun Lu
}

\section{Introduction}

Lettuce is an economically important winter vegetable crop in Florida, with approximately 11,000 acres in production and a farm gate value of $\$ 40-\$ 50$ million annually. Florida lettuce production occurs mainly in the Everglades Agricultural Area (EAA). Iceberg and romaine are the dominant types of lettuce grown in Florida. Lettuce production typically begins in late September and finishes in early May. 'Tall Guzmaine,' 'Short Guzmaine', and 'Floriglade' were the last cultivars released by the UF/IFAS lettuce breeding program (Guzman 1986); cultivars currently used in Florida lettuce production were exclusively developed by the private sector.

Although each private lettuce breeding program has its own variety trials, decisions and recommendations for the released cultivars are generally based on visual observations in the field. Data on effects of current cultivars, production locations, and their interactions on lettuce yields had been limited. In recent years, research scientists at the University of Florida conducted variety trials that included the major cultivars of romaine and iceberg types (Lu et al. 2011; Lu and Sui 2012). These trials were conducted on organic soil in the Everglades Agricultural Area (EAA) and the IFASrecommended practice was followed. In 2010, the experiments were carried out in early season with the planting date of Oct. 22 and in late season with the planting date of Jan. 23. In 2011, the experiments were carried out in early season with the planting date of Oct. 13 and in mid-season with the planting date of Nov. 26. Overall yield was lower in 2010 than in 2011 because three freezes in December 2010 caused some plant damage in early-season trials.

This document describes lettuce cultivars suitable for production on organic soils in the EAA of southern Florida.

\section{Cultivars}

'Manatee': 'Manatee' is historically important in Florida's lettuce production and was the major cultivar before 2011. However, it did not have good yield in variety trials, particularly in 2011 (Table 1) because it had low yield in the mid-season trials. Compared with other cultivars, 'Manatee' has resistance to early bolting and grows better in early growing season (from late September to early October) and in late growing season (from middle of April to early May) when temperatures are high. This cultivar can continue to be used in lettuce production in early growing season and in late growing season when other cultivars are not suitable for production due to the hot weather. 'Manatee' also has medium resistance to aphids.

'Terrapin': This romaine cultivar had the highest yield and the highest percent of marketable heads in the variety trials (Table 1). It can be planted from November to January and harvested in January through March to maximize profits.

'Okeechobee': This cultivar yielded well in the variety trials, and its yield was stable across years (Table 1). 'Okeechobee'

1. This document is HS1225, one of a series of the Horticultural Sciences Department, UF/IFAS Extension. Original publication date October 2013. Visit the EDIS website at http://edis.ifas.ufl.edu.

2. Huangjun Lu, assistant professor, Horticultural Sciences Department, UF/IFAS Everglades Research and Education Center, Belle Glade, FL 33430; UF/ IFAS Extension, Gainesville, FL 32611.

The use of trade names in this publication is solely for the purpose of providing specific information. UF/IFAS does not guarantee or warranty the products named, and references to them in this publication do not signify our approval to the exclusion of other products of suitable composition.

The Institute of Food and Agricultural Sciences (IFAS) is an Equal Opportunity Institution authorized to provide research, educational information and other services only to individuals and institutions that function with non-discrimination with respect to race, creed, color, religion, age, disability, sex, sexual orientation, marital status, national origin, political opinions or affiliations. U.S. Department of Agriculture, Cooperative Extension Service, University of Florida, IFAS, Florida A\&M University Cooperative Extension Program, and Boards of County Commissioners Cooperating. Nick T. Place, Dean. 
is suitable for production in the months from November through April.

'70096': This romaine variety yielded poorly in 2010 because it had early bolting in the late-season trials that year but had good yield in 2011 (Table 1). This variety showed strong resistance to banded cucumber beetle and was found to be cold-tolerant and seed-thermo-dormancy-resistant in the variety trials (Lu et al. 2011; Lu and Sui 2012). However, '70096' is tip-burn sensitive and is aphid-susceptible.

'Gator': It is an iceberg cultivar that has been used for lettuce production for many years. In the variety trials, it had the highest yield among the iceberg cultivars in 2010 but the lowest yield in 2011 (Table 2). However, the yields of all three iceberg cultivars were not significantly different in 2011. 'Gator' can continue to be used as a major cultivar in lettuce production in south Florida.

'8074': This variety had stable yield across years (Table 2). Although its head looks relatively smaller, leaves of the head are tightly compacted, making the head relatively heavier.

'Raleigh': 'Raleigh' is an old variety released in 1984 (Guzman 1984). This variety had low yield in 2010 but high yield in 2011. Because 'Raleigh' is an east coast type of lettuce and farmers in the EAA area no longer grow this kind of lettuce, this variety is not recommended for production.

\section{Management}

All cultivars except for '70096' and 'Raleigh' are recommended to be used for lettuce production in Florida. The following management practices for lettuce production in Florida have been designed by UF extension specialists based on research results and are available online.

Fertilization: See Hochmuth et al. $(2009 ; 2012)$ for recommendation of fertilization (http://edis.ifas.ufl.edu/wq114 and http://edis.ifas.ufl.edu/cv008).

Insect management: Information is available in UF EDIS documents CIR1460 (Mossler and Dunn, 2011, http://edis. ifas.ufl.edu/pi070) and ENY-475 (Nuessly and Webb, 2010, http://edis.ifas.ufl.edu/ig161).

Disease management: The major diseases of lettuce in Florida and their management are described in Raid (2004).

Weed control: Control of weeds in lettuce is described in Dittmar and Stall (2013, http://edis.ifas.ufl.edu/wg031).

Table 1. Marketable yield (lb/A) and marketable heads (\%) of romaine varieties grown at Belle Glade, FL, in 2010 and 2011 seasons.

\begin{tabular}{|l|l|l|l|l|}
\hline \multirow{2}{*}{ Variety } & \multicolumn{2}{|c|}{2010} & \multicolumn{2}{c}{2011} \\
\cline { 2 - 5 } & Yield & Marketable heads & Yield & Marketable heads \\
\hline Terrapin & $18,600 \mathrm{a}^{*}$ & $88 \mathrm{a}$ & $26,100 \mathrm{a}$ & $93 \mathrm{a}$ \\
\hline Manatee & $17,700 \mathrm{a}$ & $86 \mathrm{a}$ & $15,500 \mathrm{~b}$ & $77 \mathrm{~b}$ \\
\hline Okeechobee & $16,800 \mathrm{a}$ & $84 \mathrm{a}$ & $21,400 \mathrm{ab}$ & $89 \mathrm{a}$ \\
\hline 70096 & $15,300 \mathrm{a}$ & $86 \mathrm{a}$ & $22,600 \mathrm{a}$ & $89 \mathrm{a}$ \\
\hline
\end{tabular}

"Means in a column followed by the same letter are not significantly different $(P>0.05)$ using a least significant difference test (SAS Institute 2010).

Table 2. Marketable yield (lb/A) and marketable heads (\%) of iceberg varieties grown at Belle Glade, FL, in 2010 and 2011

\begin{tabular}{|l|l|l|l|l|}
\hline \multirow{2}{*}{ Variety } & \multicolumn{4}{l|}{2011} \\
\cline { 2 - 5 } & Yield & Marketable heads & Yield & Marketable heads \\
\hline Gator & $14,700 a^{*}$ & $86 a$ & $15,600 a$ & $77 b$ \\
\hline 8074 & $12,400 b$ & $83 a b$ & $18,200 a$ & $89 a$ \\
\hline Raleigh & $11,200 \mathrm{~b}$ & $79 \mathrm{~b}$ & $20,500 \mathrm{a}$ & $90 \mathrm{a}$ \\
\hline
\end{tabular}

*Means in a column within each variety followed by the same letter are not significantly different $(P>0.05)$ using a least significant difference test (SAS Institute 2010). 


\section{References}

Dittmar, P., and W. Stall. 2013. Weed Management in Leafy Greens (Lettuce, Endive, Escarole, and Spinach). HS203.

Gainesville: University of Florida Institute of Food and Agricultural Sciences. http://edis.ifas.ufl.edu/wg031

Guzman, V. L. 1984. 'South Bay' and 'Raleigh', Two Crisphead Lettuce Cultivars Resistant to Corky Root Rot for Organic Soils. Circ. S-310. Gainesville: University of Florida Institute of Food and Agricultural Sciences.

Guzman, V. L. 1986. 'Short Guzmaine', 'Tall Guzmaine', and 'Floriglade', Three Cos Lettuce Cultivars Resistant to Lettuce Mosaic Virus. Circ. S-326. Gainesville: University of Florida Institute of Food and Agricultural Sciences.

Hochmuth, G., Ed. Hanlon, R. Nagata, G. Snyder, and T. Schueneman. 2009. Fertilization Recommendations for Crisphead Lettuce Grown on Organic Soils in Florida. SP153. Gainesville: University of Florida Institute of Food and Agricultural Sciences. http://edis.ifas.ufl.edu/wq114

Hochmuth, G., E. Hanlon, G. Snyder, R. Nagata, and T. Schueneman. 2012. Fertilization of Sweet Corn, Celery, Romaine, Escarole, Endive, and Radish on Organic Soils in Florida. BUL313. Gainesville: University of Florida Institute of Food and Agricultural Sciences. http://edis.ifas.ufl.edu/ cr008
Lu, H., A. Wright, and D. Sui. 2011. "Responses of Lettuce Cultivars to Insect Pests in Southern Florida." HortTechnology 21(6): 773-778.

Lu, H., and D. Sui. 2012. Field performance of lettuce cultivars used in southern Florida. 2012 FSHS Proceedings 125:137-138.

Mossler, M.A., and E. Dunn. 2011. Florida Crop/Pest Management Profile: Lettuce. CIR1460. Gainesville: University of Florida Institute of Food and Agricultural Sciences. http://edis.ifas.ufl.edu/pi070

Nuessly, G.S., and S. E. Webb. 2010. Insect Management for Leafy Vegetables. ENY-475. Gainesville: University of Florida Institute of Food and Agricultural Sciences. http:// edis.ifas.ufl.edu/ig161

Raid, R. N. 2004. Lettuce Diseases and their Management. Diseases of Fruits and Vegetables. 121-147.

SAS Institute. 2010. Cary, NC. http://www.sas.com. 